\title{
GRENSK CULTURE IN EASTERN BELARUS: THE CURRENT STATE OF RESEARCH
}

\author{
ALIAKSANDR U. KOLASAU
}

\begin{abstract}
The article deals with the main range of problems of Grensk culture in the Final Palaeolithic and Mesolithic in the Upper Dnieper region. At present, the understanding of the ways and mechanisms of the formation and the time of habitation of members of this ancient culture are rather debatable. Interpretations of the sources have resulted in two completely different research approaches in terms of methodology, bringing together supporters of the indigenous (U. Budzko, V. Kapytsin, A. Kalechyts, G. Sinitsyna, etc) or migration (L. Zaliznyak, U. Ksiandzou, A. Sorokin, etc) ways of the emergence and the development of Grensk culture. It is impossible to understand the essence of the 'Grensk question' without considering the nature of its origin, the problem looked at in this article.
\end{abstract}

Key words: Final Palaeolithic and Mesolithic, Grensk culture, eastern Belarus, Upper Dnieper region, asymmetrical shouldered points, Ienevo culture, Pesochny Rov culture.

DOI: http://dx.doi.org/10.15181/ab.v25i0.1828

\section{Introduction}

During the Late Pleistocene and Early Holocene, a number of archaeological cultures developed in Europe, for which literature on the Final Palaeolithic has a special name: 'tanged point cultures' (Kozlowski 1999; Kalechyts et al. 2010). This definition is not accidental, because it reflects qualitative changes in the culture and economy of mankind which occurred at the end of the last glacial period. These changes were naturally associated with the disappearance of the mammoth fauna complex and the wide spread of reindeer at the end of the Late Glacial period, which marked an era of seasonal migration of the ancient population and stimulated the emergence of new forms of hunter economy based on the use of remote weapons: bows and arrows.

The concept of 'tanged point cultures' is reflected in the materials of some closely related cultures, which, for clear reasons, have become a kind of source tool in solving regional problems of the Final Palaeolithic and Mesolithic. An example of this is the groups of sites characterised by the widespread tradition of asymmetrical shouldered points and arrowheads.

On this basis, for instance, in the Upper Dnieper region, a group of sites have been united under the name Grensk culture (Bud'ko 1966; Kopytin 1992; Kopytin 1999; Kopytin 2000; Ksenzov 1997; Ksenzov 1999; Ksenzov 2006; Kozlowski 1999; Kalechyts et al. 2010). In the Volga and Oka interfluves, sites with asymmetrical shouldered points appear under the name Ienevo culture (Kravtsov, Sorokin 1991; Kravtsov 1999; Sorokin 2006; Sorokin et al. 2009). In the Desna region, sites of Pesochny Rov type, or Pesochny Rov culture, are known (Zalizniak 1999; Zalizniak 2005). Polish historiography refers to all sites with asymmetrical shouldered points as Desna culture (Kozłowski 1991; Kozlowski 1999; Szymczak 1995; Sulgostowska 2005), and the Ukrainian archaeologist L. Zaliznyak combined all of them into the separate Krasnosillya culture, which is one of the binding stages in the evolution of the tradition of flint processing of east Lyngby (Zalizniak 1999; Zalizniak 2005).

In any case, all the above cultures share a common feature: a special form of point (arrowhead), i.e. asymmetrical shouldered points. It was this particular geometry of weaponry, as well as methods for the primary and secondary processing of stone, that determined the long-term evolution of the culture of the Palaeolithic population of the East European Plain during the transformation of the environment at the turn of the Pleistocene and the Holocene.

Therefore, in this article, I propose to consider one of the most urgent problems in modern historiography connected with the genesis and timeframes of Final Palaeolithic and Mesolithic in eastern Belarus, based on materials of the mentioned Grensk culture. This will determine the condition of and prospects for the further study of this largely controversial phenomenon, from a historiographical point of view, as well as helping to understand changes in the culture of ancient people who inhabited western regions of Eastern Europe during the Late Pleistocene and Early Holocene. This article is part of the author's research programme devoted to the study of the Final Palaeolithic and Mesolithic in eastern Belarus. The results were published 
in a series of articles, and a monograph by the author (Kolosov 2010; Kolosov 2013; Kolosov 2015), and a joint monograph with A. Kalechyts, A. Kolasau, W. Obuchowski (2010), which summarised the information on the Palaeolithic in Belarus.

\section{Materials}

About 130 Final Palaeolithic monuments are known in the Upper Dnieper basin (Kalechyts et al. 2010; Kolosov 2015). The materials from most of the sites have been obtained by surface collection, which makes it difficult to develop a chronology of the Final Palaeolithic and search for the genetic basis of the cultures identified here. The solution to these issues is complicated by the absence of faunal remains on the monuments, and the general lack of any data for natural-science research and the absolute dating of materials.

In addition, it was discovered that groups of hunters from different cultures often occupied the same convenient places for their settlements, which ultimately led to the mixing of materials. The cultural layer of Upper Dnieper Final Palaeolithic sites is not expressed stratigraphically, and is confined to sandy soils, which preserved the only source of information, i.e. flint products. It is impossible to determine the precise boundaries of a settlement of any culture, or the number of visits to the sites. The similarities and the differences between monuments are determined on the basis of the techno-morphological analysis of the flint inventory, and a comparison of data obtained with materials from neighbouring areas.

Now let us turn to a consideration of Grensk culture in eastern Belarus. This culture was named after the site of Hrensk, located on the right bank of the River Sozh to the east of the village of Vornaŭka in the Karma district of the Homiel region of the Republic of Belarus. The scientific basis for the culture was obtained in works by U. Budzko (1966), A. Kalechyts (1987; 2003), U. Ksiandzou (Ksenzov 1988; 1997; 1999; 2006), and V. Kapytsin (Kopytin 1992; 1999; 2000; 2005). Problems in the study of Grensk culture were considered in publications by L. Zaliznyak (1999; 2005; 2009), S.K. Kozłowski (1991; 1999), A. Kravtsov and A. Sorokin (1991), K. Szymczak (1995), A. Kravtsov (1999), A. Sorokin (2002; 2004; 2006; 2008; 2009; 2016), A. Chubur (2004), Z. Sulgostowska (2005), G. Sinitsyna (2008; 2013), A. Kolasau (Kolosov 2010; 2013; 2015), S. Lisitsyn (2017), and others.

At present, there are more than 40 points in Belarus with materials of Grensk culture (Fig. 1). The majority of Grensk culture sites are localised within the Upper Dnieper region: in the Dnieper basin, Baroŭka (the sites mentioned here and below have only been studied by excavation), Daĺniaje Liada, Karomka, Ludčycy, Maloje Zarečča (Škloŭ Zarečny), Mahilioǔskaja, Orša-1, Rekord, Chvojnaja; in the Sozh basin, Hrensk, Žuravieí, Paklady-2; in the Biesiadź basin, Vituń-5A, Pechenezh; in the Biarezina basin, Huta-1; in the Druć basin, Viryčaŭ, Višańka, Čyhirynka (Ksenzov 1988; Ksenzov 2006; Kopytin 1992; Kopytin 2000; Kalechyts et al. 2010; Kolosov 2015).

In Belarus, asymmetrical shouldered points have been found at some sites in the Nemunas and Pripyat basins (Obukhovskii 2007; Obuchowski 2009). They are also typical of monuments of Ienevo culture in the Volga and Oka interfluve (Kravtsov, Sorokin 1991; Sorokin 2004, pp. 76-78), as well as for Pesochny Rov culture in the Desna basin (Zalizniak 1999, pp. 96-101; Zalizniak 2005, pp. 55-62). Sites with asymmetrical shouldered points are found in eastern Poland (Desna culture) (Obukhovskii 2007; Kozłowski 1991; Kozlowski 1999; Szymczak 1995, p. 70; Sulgostowska 2005, pp. 123-133). They are also known in Lithuania (Rimantienè 1971) and northern Europe (Taute 1968; Kozłowski 1991; Kozlowski 1999; Zalizniak 2005).

In eastern Belarus, sites of Grensk culture are topographically bound to different types of relief: 1) the edge or the headland of the first floodplain terrace standing four to seven metres high above the floodplain level (Viryčaŭ, Višańka, Hrensk, Huta-1, Žuravieĺ, Mahilioŭskaja, Paklady-2, Čyhirynka); 2) the edge or headland of the second floodplain terrace, ten to 24 metres high (Baroŭka, Daĺniaje Liada, Karomka, Mahilioŭskaja, Orša-1, Rekord, Chvojnaja); 3) the indigenous bank of a river (Maloje Zarečča [Škloŭ Zarečny]) or a lake (Piečaniež). The cultural layer of most of the sites is bound to the illuvial horizon of the soil, and is determined according to the level of vertical distribution of the findings in the profile, at a depth of 0.1 to 0.6 metres from the day surface. Only at the Chvojnaja site was a 0.15 -metre-thick cultural layer found in buried soil at a depth of 0.9 to 1.06 metres, which made it possible to draw conclusions about the geological age of the monument (Kopytin 1992, p. 25).

The poor preservation of the cultural layer at the sites creates problems in the study of the settlement structure of this cultural phenomenon in the Upper Dnieper basin. At present, it is possible to specify only three sites of Grensk culture where the remains of household objects are documented: Hrensk (Bud'ko 1959; Bud'ko 1961; Bud'ko 1962, pp. 11-41; Bud'ko 1966), Ludčycy (Kopytin 1992, pp. 38-40, Fig. 9) and Paklady-2 (Kolosov 2005).

The first information about the existence of any habitat structures at Grensk sites was obtained by U. Budzko

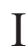

STONE AGE IN NORTHERN EUROPE: CHANGES IN LANDSCAPE, TECHNOLOGIES AND BELIEFS 


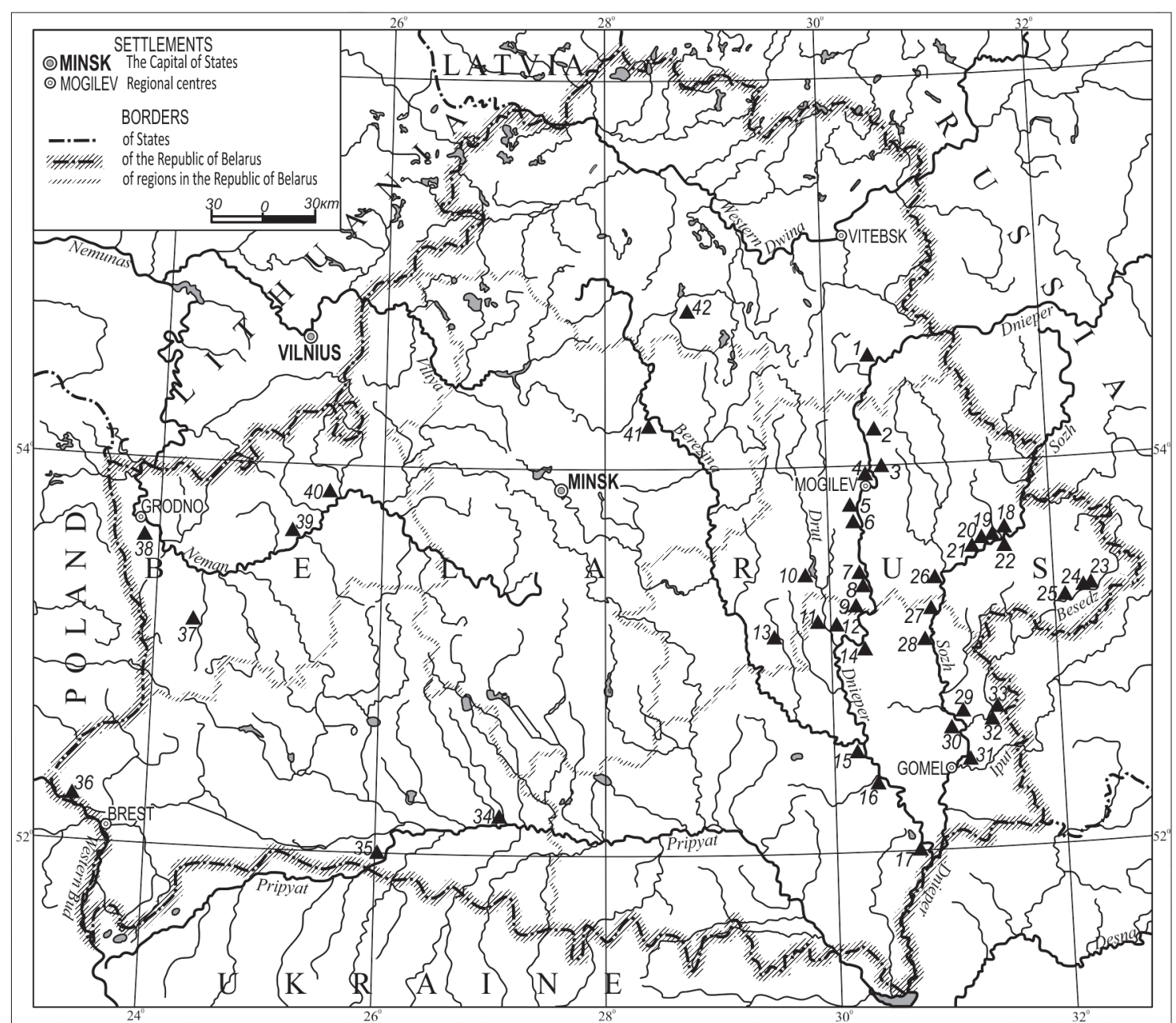

Fig. 1. Map of Final Palaeolithic and Early Mesolithic Grensk culture sites in Belarus. 1 Orša-1; 2 Maloje Zarečča (ك̌kloŭ Zarečny); 3 Chvojnaja; 4 Mahilioŭskaja; 5 Baroŭka; 6 Daĺniaje Liada; 7 Ludčycy; 8 Tajmanava; 9 Karomka; 10 Čyhirynka; 11 Viryčaŭ; 12 Višańka; 13 Vialikija Bortniki; 14 Zbaroŭ-2; 15 Bierahavaja Slabada; 16 Rečyca-2;

17 Rekord; 18 Paklady-2; 19 Čerykaŭ-6; 20 Horki; 21 Žuravieĺ; 22 Hronaŭ-1; 23 Vituń-5A; 24 Vituń-4; 25 Piečaniež; 26 Rudnia; 27 Licvinavičy; 28 Hrensk; 29 Pralietarski-1A; 30 Prysno-2; 31 Klionki-3; 32 Rudnia Sponickaja (Latki); 33 Novyja Hramyki-4; 34 Borki; 35 Lasick-3; 36 Halačeva-2; 37 Krasnasieĺski-6; 38 Kavaĺcy-4; 39 Zbliany-2; 40 Moryna-2; 41 Huta-1; 42 Piesčanica.

in 1959 during his study of the site at Hrensk. He noted the remains of a hearth (or hearths?) surrounded by a lot of split flint, charcoal and bone coal (Bud'ko 1959; Bud'ko 1961; Bud'ko 1962, pp. 11-41; Bud'ko 1966). Unfortunately, V. Kapytsin, who continued the study of the Hrensk site in the 1970s and 1980s, failed to find any more household objects there (Kopytin 1992, pp. 32-38; Kopytin 1994).

V. Kapytsin also studied the remains of a rounded dwelling up to 2.5 metres in diameter at the Ludčycy site in 1973 (Kopytin 1992, pp. 38-39, 73, Fig. 9). The structure was deepened into the mainland at 0.1 to 0.2 metres. In the centre of the dwelling, there was a concentration of charcoal, which, according to V. Kapytsin, proves the presence of a hearth. There was another hearth 0.6 metres in diameter two metres to the west of the dwelling. A cluster of stones was found near it, apparently used as a wind barrier.

The remains of a rounded pillar $\left(0.26^{*} 0.35^{*} 0.12\right.$ metres) and a hearth $(0.45 * 0.50 * 0.08$ metres $)$, found at a depth of 0.48 metres from the surface, were studied during the excavations at the Paklady-2 site in the midSozh region (Kolosov 2005). To the south of these objects, at a depth of 0.78 metres, one more oval-shaped hearth was found; it resembled a figure ' 8 ', with a size of $1.06 * 0.62 * 0.10-0.20$ metres.

The concepts of Grensk culture are formed as a result of the study of the flint implements from its monuments, the only source of information, which allows us, to varying degrees, to discuss the specifics of Grensk antiquities compared to other Final Palaeolithic and Mesolithic cultural phenomena in the Upper Dnieper 
region. This originality is highlighted by the nature of the primary and secondary processing of flint.

The flint industry of Grensk culture was based on the exploitation of local deposits of raw materials, i.e. grey chalk flint. A distinctive feature is the presence of various inclusions of chalk and other substances of organic and inorganic origin, which affected the quality of the raw material, and in the course of further use it was the reason for its rejection.

The availability of raw materials has left its imprint on the nature of the development of the flint industry of Grensk culture. The implements at the sites located in the outlet areas of raw materials contain numerous nodules and chips of flint with negatives of two or more random splits, as well as a large amount (up to $80 \%$ ) of production waste. In the instrumental activity, there is an aspiration to use naturally broken fragments of flint.

The splitting technique in Grensk culture was based on the principle of the parallel removal of workpieces from a one-sided surface, which gradually passed to the sides of the cores until its complete utilisation. Among the cores, single-platform cores prevail (40\% to $60 \%$ ), with a small number of double-platform ones (Fig. 2.33-34). There are a few groups of triple-platform cores (Hrensk), discoid cores with radial workpiece chipping (Piečaniež), and multi-platform cores.

Grensk culture is characterised by the use of solid crack techniques, as is evidenced by the findings of flint fabricators (Hrensk, Žuravieĺ, Paklady-2) and the morphology of the chips. Basic blanks for tools are presented by flakes, rarely by blades with irregular cutting. At their proximal portions, chips save the expressive bulb of percussion, and the rudiments of a broad, smooth, and in some cases crusted, surface of the striking platform. On the main part of the blanks, cracking ripples can be noticed. Traces of pre-reduction of the edge of the striking platform are missing.

The presence at Grensk sites of materials of other cultures brings up the question of the number of tool types of which the shape changed slightly during the Stone and Bronze ages: scrapers, burins, borers, notched tools, and others. The collections from Grensk sites include end-scrapers (the prevailing type), as well as double end, circular end, orgival end and thick-nosed scrapers (Fig. 2.21-23). It is believed that scrapers are the dominant group among all the tools in Grensk culture (Kopytin 1992; Ksenzov 1988; Ksenzov 2006). Among the secondary processed flint tools, there is a great variety of burins (Fig. 2.28-30). The most common types of these products include burins on a truncated piece, angle burins, straight dihedral and combined burins.
The complex of Grensk tools is complemented by: notched tools; angle and dihedral borers; symmetrical and asymmetrical points, some with beak ending; pieces with oblique retouched truncation; backed blades (total backing); chopping tools in the form of wedgeshaped axes and hatchets with interception (Fig. 2).

Thus, the data obtained proves that in secondary flint processing, the Grensk population used widely the retouching of blanks in order to change their form, and the technique of chopped burin production.

But the defining feature which determines the peculiarity of Grensk culture is the form of the points (arrowheads) (Fig. 2.1-16). Two basic forms of arrowheads are distinctive of the Grensk tradition.

One of them is the 'simple tanged points', with different variants of tangs and points (Fig. 2.1-8). Among them are asymmetrical shouldered points retaining the natural outlines of the blank without additional processing. The tips of some points are corrected with a retouch, and, depending on the location, create the following variations: 1) the retouch is applied only from the back, or 2) is located exclusively on the front, or 3) is opposite. Some points can be oblique and resemble the 'Ahrensburg type' known in literature. Their differences are: the tips of the points are formed in the distal part of the blade flakes, at some sites (Hrensk, Karomka) the tips are additionally trimmed with burin chopping.

Shouldered points are different in the design of the tang. The most characteristic feature of this group of tools is the sharp or semi-sharp retouching of the tang on the back. The tang part was formed at the proximal end of a blade flake. The base of the tangs of such points in some cases can be broken or retouched, which brings these variants together with points of Volkushian culture of northeast Poland and western Belarus (Szymczak 1995, pp. 31-48; Obuchowski 2009). There are also points with tangs formed by an opposite retouch. Finally, some tangs are formed by a semi-abrupt retouch from the ventral side (Hrensk, Žuravieí).

The second group is represented by asymmetrical shouldered points (Fig. 2.9-16). In the special literature, the points of this form are referred to as 'Hrensk type', 'Hrensk points' (Kalechits 1987; Kalechits 2003; Kopytin 1992; Kopytin 2000; Ksenzov 1997; Ksenzov 2006), 'Altynovo-type inserts' (Kol'tsov 1972), and 'points' (Ageeva 2007). The shape of the points is formed by the full or partial retouching of one of the edges of a blade flake; the opposite side of the tang is marked as a notch. The points have a wedgeshaped section. V. Kapytsin noted the technical connection between the morphology of the blade flake, the

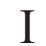

STONE AGE IN NORTHERN EUROPE: CHANGES IN LANDSCAPE, TECHNOLOGIES AND BELIEFS 

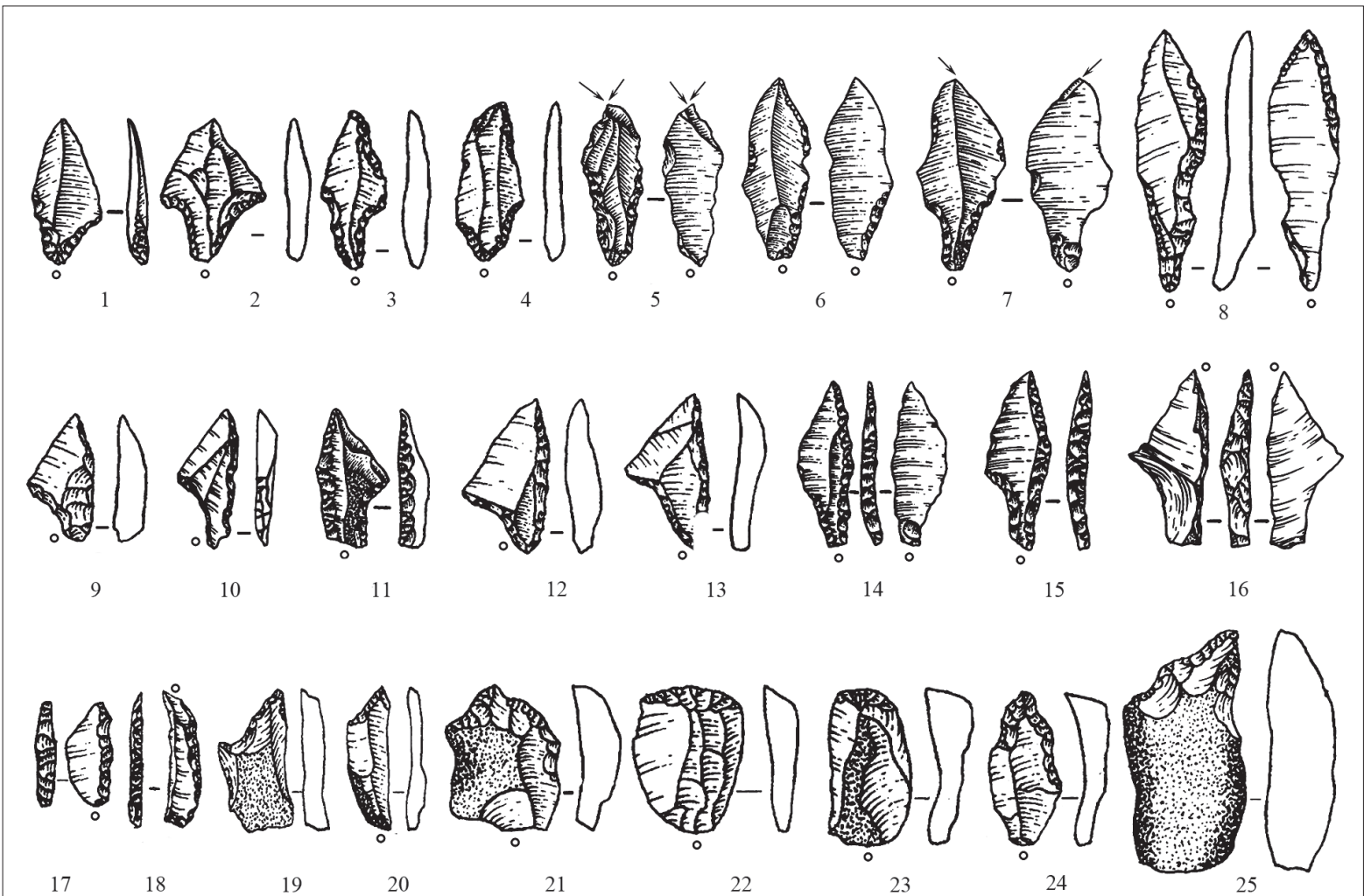
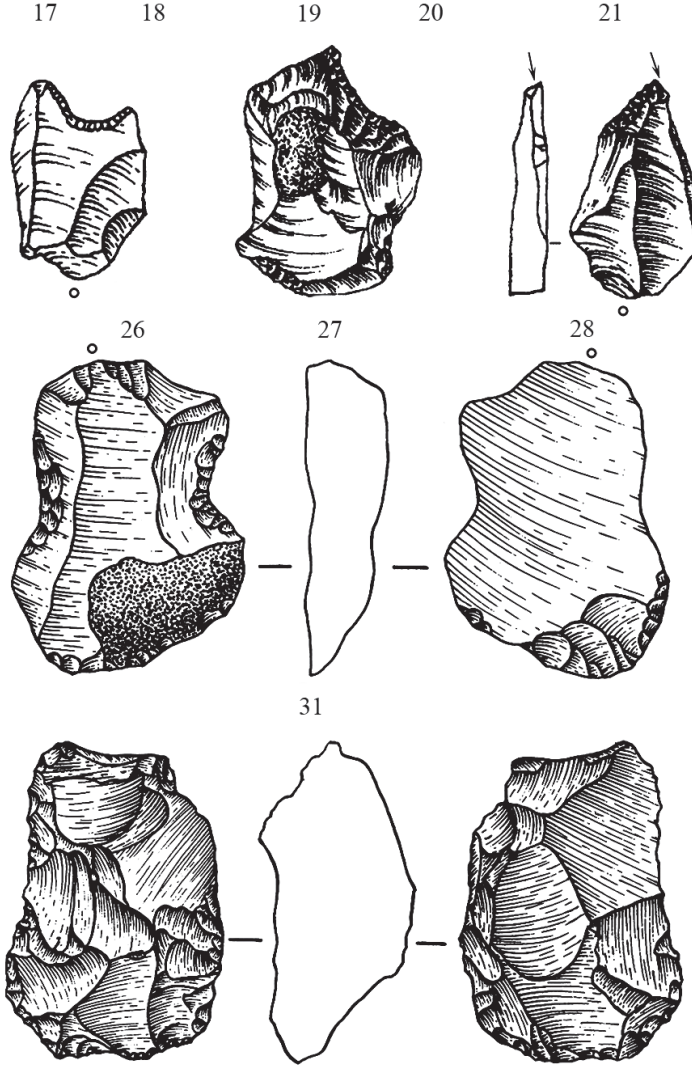

$0, \quad, \quad 3, \mathrm{~cm}$

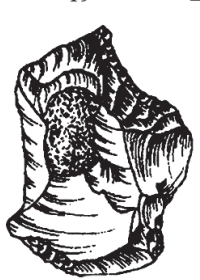

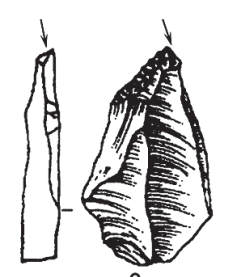
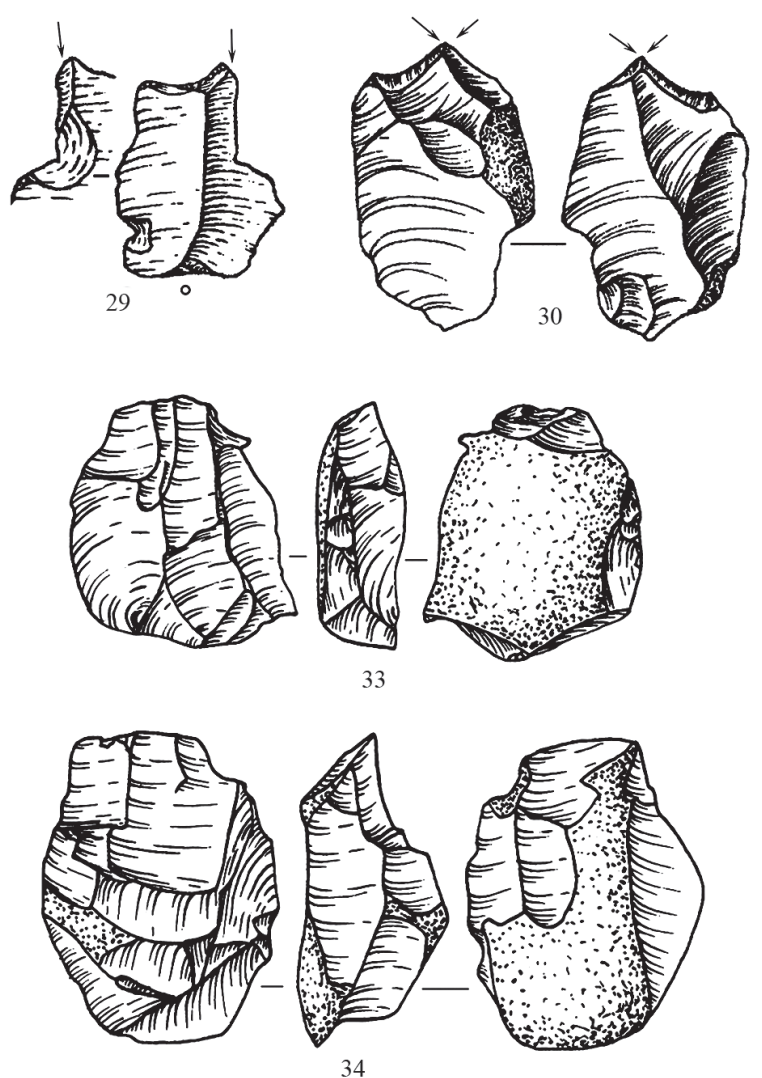

Fig. 2. Grensk culture flint tools (from sites in eastern Belarus): 1-16 points (arrowheads); 17-18 backed bladelets; 19-20 pieces with oblique retouched truncation; 21-23 end-scrapers; 24-25 points; 26-27 notched pieces; 28-30 burins; 31-32 chopping tools; 33-34 cores (1, 5-7, 11, 14-15, 31-32 Karomka; 2-4, 8-9, 12-13, 17-30 Baroŭka, 10, 16, 33-34 Paklady-2; after Kopytin 1992; Kolosov 2005). 
ways of its secondary processing, and the very form of asymmetrical points (Kopytin 2000, pp. 42-43). The latter, according to V. Kapytsin, were supposed to provide a pricking-cutting wound (Kopytin 2000, p. 43). The functional study of this group of tools shows that they were used not only as arrowheads, but also as inserts for hunting weapons (Kol'tsov 1972, pp. 89-90; Kravtsov, Zhilin 1995). Some notched points preserve traces of puncturing skin (Poplevko 2007, pp. 202-211, Table XLVI).

The classification of asymmetrical shouldered points was proposed in the work of V. Kapytsin (2000), W. Obuchowski (2007) and K. Ageyeva (2007). Summarising all the proposed schemes, we should note that, according to the type of blank among asymmetrical shouldered points, there are some on flakes and blades. The tang of a point can be located both at the proximal and distal ends of a blank. According to the shape of the tip, the points can have a straight or a convex edge.

Some typological peculiarity belongs to those asymmetrical shouldered points for which a blade of narrow or elongated proportions was used as a blank. One of the side laterals of a blade was completely dulled by semi-abrupt retouching, while its opposite side was marked by a notch of a third or half the length of the blank. According to their shape, these points on the blades occupy an intermediate position between the proper asymmetrical shouldered points and shouldered points. The base of such points could be specially broken or processed by retouching.

A separate group is formed by points with tangs additionally processed with flat ventral retouching. They are found both among shouldered points (especially points with oblique tips) and asymmetrical shouldered points with a lateral notch (Hrensk). Such forms of weaponry are classified as hybrid (Butrimas, Ostrauskas 1999, pp. 267-270, Fig. 4; Sorokin 2002, pp. 132150). It is believed that they combine features of the flint processing traditions of the non-Swiderian, in our case the Grensk, population (due to the shape of the points), and the Swiderian population (due to the flat retouching of the tangs).

However, the origin of the so-called 'hybrid' forms of points remains unclear. First, such points are represented by single specimens, and the correction of a tang by flat retouching in this case can be considered accidental. Second, we cannot exclude the independent formation of the method of flat retouching of tangs which is not characteristic of Grensk culture as a whole. Grensk points are characterised by a transverse truncation of the projecting percussion by one or two or more unidirectional clefts, which certainly led to a thinning of the basal part of a tang. In our opinion, there is some difference between classic Swiderian methods of processing the tangs of points, with flat ventral retouching being more accurate and sustained, and the 'Grensk' one.

Thus, from the 1960s, since the moment of the detachment of Grensk culture by U. Budzko (1966), a representative source base has been accumulated which made it possible to considerably broaden our views on the settlement of eastern Belarus during the disappearance of the last glacier. However, in the process of the generalisation of material in the late 1980s and 1990s, in the historiography of the Final Palaeolithic, a series of problems connected with the genesis and chronology of monuments of Grensk culture emerged (Kopytin 1992; Kalechits 2003; Zalizniak 2005; Ksenzov 2006). At present, Grensk problems are complemented by the definition of the place of this culture in the Final Palaeolithic and Mesolithic of the western part of the East European plain (Sorokin et al. 2009). One of the most topical is the question of the adaptation of the Grensk population after the end of the last glacial epoch, i.e. in the Mesolithic.

\section{Questions of origin}

The question of the genesis of this cultural phenomenon was raised for the first time in the work of $U$. Budzko (1966, pp. 35-44). He connected the formation of 'Swiderian-Grensk culture' (the name he originally proposed for this cultural phenomenon) with the traditions of Kostenki-Avdeevka, Eliseevichi, Yudinovo, Timonovo late Palaeolithic cultures (Bud'ko 1966, p. 42). However, this assumption lacked a firm fact base, and therefore it attracted critics (Kopytin 1992, p. 11; Kopytin 1999; Ksenzov 2006, pp. 16-36).

In any case, even at the stage of the formation of the ideas about the genesis of Grensk culture, a trend developed in historiography which tried, and is still trying, to prove the kinship of 'Grensk' with the traditions of the Late Palaeolithic of the centre of the Russian Plain.

The concept of the autochthonous character of Grensk antiquities of the Upper Dnieper region was most thoroughly established by V. Kopytin (1992; 1999; 2000). Thus, the Grensk population, according to this researcher, was a direct genetic descendant of the late Palaeolithic Mezin cultural tradition. Kapytsin's conclusions were based on an analysis of all typical forms of flint implements of Grensk monuments, making it possible to discover a 'striking similarity' between Mezin and Grensk traditions in flint processing (Kopytin 1992, pp. 10-27; Kopytin 2000).

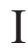

STONE AGE IN NORTHERN EUROPE: CHANGES IN LANDSCAPE, TECHNOLOGIES AND BELIEFS 
Kopytin's ideas on the genesis of Grensk culture are shared by A. Kalechyts (2003) and A. Chubur (2004). Chubur agreed fully with Kapytsin. He considers that Grensk culture derived from flint processing within the 'Gmelin-Mezin evolution branch', a special role being played by a variant of Mezin archaeological culture, Dnieper culture (the Middle Dnieper group) (Chubur 2004, pp. 46-49). At the same time, A. Chubur tries to link the genesis of individual Grensk sites with sites of 'Byki-Mezin-Suponevo' type, as well as Mezhirichy and Dobranichevka (Chubur 2004, pp. 48-49).

In her turn, A. Kalechyts thinks it is necessary to search for a local substrate, and a possible link between Grensk and Bierdyž traditions, which is supported by a later date for this Late Palaeolithic site in eastern Belarus: $15100 \pm 250$ years (OxA-716) (Kalechits 2003, p. 54). A similar view of the possible connection between Grensk culture and the Late Palaeolithic Age of the Russian Plain was expressed by U. Budzko. He saw continuity in the forms of tanged points in early sites of Grensk culture and side-notched shouldered points of Kostenki-Avdeevka culture (Bud'ko, Sorokina 1969).

At present, ideas of the autochthonous origin and development of Grensk antiquities are propounded by the Russian researcher G. Sinitsyna (2008, pp. 168-170). In her opinion, Grensk culture is a vivid example of the development of the local traditions of the entire Late Magdalenian culture area, which formed in the Upper Dnieper region during the Late Pleistocene and Early Holocene. This fact is proven not only by the specific features of Grensk flint implements, which, according to G. Sinitsyna, are noticeably different from the Bromme-Lyngby techno-complex, but also by the natural science dates obtained by her for Final Palaeolithic sites in the Valdai Hills, which is to be discussed later.

The opposing view of the genesis of Grensk culture was offered by the Ukrainian archaeologist L. Zaliznyak and the Belarusian researcher U. Ksiandzou (Ksenzov 1997, pp. 7-11; Zalizniak 2005; Ksenzov 2006). From the standpoint of migrationism, L. Zaliznyak united all Grensk sites within Krasnosillya culture. He derived its origin from the cultural traditions of east Lyngby. In his opinion, during the Allerød oscillation and Younger Dryas, the Lyngby population migrated over a vast area from the Oder basin to the Upper Volga (Zalizniak 2005, pp. 44-51). Some Lyngby hunters migrated southeast and became the genetic basis for Krasnosillya culture. Geographically, this culture covered the Upper Nemunas region, Pripyat Polesie and the Upper Dnieper region. L. Zaliznyak's main argument in favour of his idea of the western origin of Krasnosillya culture is the presence of Lyngby points in its flint complexes (Zalizniak 2005, pp. 44-49).
L. Zaliznyak's opinion regarding the genesis of Grensk culture, as is mentioned above, is shared by U. Ksiandzou (1997; 2006). Based on the forms of arrowheads, U. Ksiandzou initially traced the origin of Grensk culture within the Ahrensburg tradition, and later on the Lyngby tradition (Ksenzov 1997, pp. 7-11; Ksenzov 2006, pp. 16-39).

According to U. Ksiandzou, Grensk culture was preceded by Anosovo and Berestenovo sites in the Upper Dnieper region. He associated the materials from these sites with the Lyngby tradition, which, as he stated, became 'the definite genetic basis for Grensk culture' (Ksenzov 2006, pp. 16-39). U. Ksiandzou proved that the Lyngby population migrated to the Upper Dnieper region from the west. The evidence for the 'western' origin of early Grensk complexes was the similarity between tanged points known in Lyngby sites in the Nemunas basin and Pripyat Polesie (Ksenzov 1997, p. 11; Ksenzov 2006, p. 36).

However, V. Kapytsin denied the possibility of the formation of Grensk culture on the basis of Lyngby. The researcher explained the spread of tanged points similar to Lyngby ones by the convergent development of Final Palaeolithic cultures in Eastern Europe in similar environmental conditions (Kopytin 2000, pp. 134-135). 'The apparent similarity of these cultures,' V. Kapytsin wrote, 'can be explained by the similar organisation of the life of reindeer hunters in similar natural conditions and engaged in similar types of economic activity, which implies a similar solution to certain technical tasks in the creation of hunting weaponry ... over a vast territory' (Kopytin 2000, p. 135).

Today, the possibility of segregating the monuments of Bromme-Lyngby culture in the Upper Dnieper region requires the use of a reliable source base. We can specify ten sites at which the shouldered shape of arrowheads reminiscent of the Bromme-Lyngby type is found: $\mathrm{Bi}$ erascienava, Daĺniaje Liada-3, Karomka, Chvojnaja (the Dnieper river basin), Hlušnieva-2, Vazniasiensk-1 (Muraviec-1), Klionki-5 (Ilíic), Pieršakryčaǔski-3, Čamiarnia and Čerykaŭ-2 (the Sozh river basin). At individual sites, this type of point is combined with points of Grensk type (Karomka, Chvojnaja) and Swiderian type (Karomka). Collections from most of the sites are represented mainly by surface gatherings, and only at some sites (Bierascienava, Karomka, Pieršakryčaŭski-3, Chvojnaja, Čerykaŭ-2) were findings obtained as a result of excavations (Kalechyts, Kolasau, Abukhouski 2010).

The difference between materials of the above-mentioned sites and Bromme-Lyngby culture itself is quite obvious. It is manifested clearly in the shapes of some arrowheads, which was stressed by G. Sinitsyna (Sin- 
itsyna 2013). Comparing the points from some Upper Dnieper sites (Anosovo-1, Ladyzhino-3) with classic Bromme-Lyngby forms of points, G. Sinitsyna shows a noticeable difference between them (Sinitsyna 2013, p. 166). For Anosovo points, for example, she distinguishes a number of distinctive features (Sinitsyna 2013, p. 166): 1) the points have the form of a parallelogram or rhombus; 2) 'the percussion bulb is retouched'; 3) the percussion bulb can be 'located at the tip'.

However, the Russian researcher A. Sorokin does not see any fundamental difference between Grensk, Pesochny Rov and Ienevo cultures (Sorokin 2008, pp. 128-144; Sorokin, Oshibkina, Trusov 2009, pp. 168176; Sorokin 2016, pp. 194-205). He unites all these cultures within 'Ahrensburg culture', and explains the broad territorial distribution of its monuments as the result of the seasonal migration of reindeer hunters in a meridional direction. This solution simplifies the view of the genesis and chronology of the culture of asymmetric shouldered points from the woodlands of Eastern Europe, but it also has some weak spots, because the flint inventory of Grensk, Pesochny Rov and Ienevo cultures lacks a stable set of characteristics peculiar to Ahrensburg culture.

This issue was emphasised by S. Lisitsyn (2017). Based on data from the palaeo-geography of the Late Glaciation and Early Holocene of the Upper Volga region, some ethnographic observations and the ethology of reindeer (primarily the forest population), S. Lisitsyn came to the conclusion that there is a local specificity of related, but not identical in their stone inventory, cultures of Grensk, Ienevo and Pesochny Rov, on the one hand, and of Ahrensburg on the other (Lisitsyn 2017, pp. 70-73).

Thus, the presence of Bromme-Lyngby points at sites of Grensk culture has several reasons. On one hand, we can note the genetic connection between the BrommeLyngby traditions and the industries of Grensk culture. On the other hand, it is impossible to exclude the convergent way of the appearance of shouldered points in Grensk culture similar to the Bromme-Lyngby and Ahrensburg type. Thirdly, taking into account the mixed nature of the materials from a number of monuments of Grensk culture, a variant of the presence in the collection from the same monument of both Grensk and Bromme-Lyngby finds is possible. However, while in the first case the question of the genetic roots of Grensk culture is solved uniquely, the second and the third variants leave the 'Grensk problem' still open.

\section{The problems of chronology}

The timeframe of Grensk culture is no less controversial. The reason for this is the lack of stratified sites and natural sciences data which would allow for the absolute dating of materials and their binding to the palaeogeographic situation in the Late Glacial period. The Grensk culture Chvojnaja site was attributed to the early Older Dryas by V. Kapytsin on the basis of stratigraphic observations (Kopytin 1992, pp. 25-26). However, the absence of natural science dating demands very accurate conclusions about Chvojnaja's geochronology. Therefore, whatever the views on Grensk culture chronology are, each of them is based primarily on the results of comparative and typological analysis of the flint inventory, and this fact naturally reduces the possibilities for solving this problem.

The first chronological scheme for Grensk culture was proposed by U. Budzko (1966). It was based on data from the Hrensk, Padlužža and Karomka sites. Stratigraphic observations and the idea for the evolutionary development of tools made it possible for U. Budzko to distinguish three chronological stages in the development of 'Swiderian-Grensk culture'. Monuments of the first stage were attributed to the Older Dryas. The second stage was no later than the Bølling interstadial. The third stage coincided with Allerød (Bud'ko 1966). However, the further study of Grensk sites showed the fallacy of U. Budzko's views, and proved the impossibility of their application to chronology issues (Kopytin 1992, pp. 10-27, 32-47; Arkhealogiia Belarusi 1997, pp. 39-55; Ksenzov 2006, pp. 23-25).

V. Kapytsin singled out two chronological groups of Grensk monuments (Kopytin 1992, pp. 10-27, 3247; Arkhealogiia Belarusi 1997, pp. 39-55). The first group included the Baroŭka, Karomka and Chvojnaja sites, attributed to the Final Palaeolithic period (12,000 to 10,000 years ago). The second chronological group was represented by the Hrensk, Mahilioŭskaja, Ludčycy, Čyhirynka sites, and dated to the Early Mesolithic period (10,000 to 8,000 years ago). This chronological division of Grensk materials, according to V. Kapytsin, was justified by peculiarities in the topography of the sites. He suggested that all early Mesolithic sites were located below 150 metres above sea level (Arkhealogiia Belarusi 1997, p. 46), which is not confirmed by modern research. V. Kapytsin placed a nominal boundary between the Final Palaeolithic and Early Mesolithic complexes, and based it on the concept of the evolutionary development of the flint splitting technique and some forms of tools (Kopytin 1992, p. 32; Arkhealogiia Belarusi 1997, pp. 45-46).

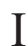

STONE AGE IN NORTHERN EUROPE: CHANGES IN LANDSCAPE, TECHNOLOGIES AND BELIEFS 
A. Kalechyts shared Kapytsin's chronological ideas in general, but taking into account new palaeogeography data, she suggested considering Grensk culture two or three millennia older, because 'the area of eastern Belarus to the south of Orša could have been inhabited through almost the entire Late Glacial period, even from the 15th millennium $\mathrm{BC}$ when the glacier finally left the borders of Belarus' (Kalechyts 2003, p. 53). This opinion was in the main shared by A. Chubur, who dated the Grensk sites to 'between 11,000 and 13,000 years ago' (Chubur 2004, p. 49).

There has been new geomagnetic dating for the Final Palaeolithic sites in the Valdai Hills (Baranova Gora, Podol-3), some of which show a typological similarity to Grensk sites (Vyshegora-1). Therefore, G. Sinitsyna proposes 'to return to U. Budzko's point of view, which dated the middle group of Grensk culture between Bølling and Allerød, i.e. 12,700 to 11,800 years ago, which corresponds to the age of the buried soil in the Vyshegora-1 site' (Sinitsyna 2008, p. 170).

Sinitsyna's materials undoubtedly open up new perspectives in solving the problems of the genesis and history of Grensk culture, and the nature of the cultural and historical links of the population of the Upper Dnieper region in the Late Glacial period. However, we should keep in mind that U. Budzko's conclusions on the chronology of 'Swiderian-Grensk culture' are based on a flawed source system (Kopytin 1992, pp. 10-27, 32-47; Arkhealogiia Belarusi, pp. 39-55); thus, there is no need to impose the absolute dates obtained for Valdai monuments on U. Budzko's chronological scheme. Besides, we cannot exclude the possibility that the dating obtained by G. Sinitsyna may be incorrect towards the archaeological materials (Lisitsyn 2017, pp. 87-90).

L. Zaliznyak, considering the chronology and periodisation of Krasnosillya culture, has attributed its flint industry to the Younger Dryas (Zalizniak 2005, pp. 4651). He believes that at the end of the Allerød oscillation and the beginning of the Younger Dryas cooling, eastern Lyngby sites transformed into Krasnosillya culture. The latter in the Early Preboreal became the basis for the formation of Ienevo and Pesochny Rov antiquities (Zalizniak 1999, pp. 96-101; Zalizniak 2005, pp. 46-51, 62). According to L. Zaliznyak, the Upper Dnieper monuments of Borovka type were transitional from Krasnosillya culture to Ienevo and Pesochny Rov cultures.

U. Ksiandzou proved that Grensk culture was Late Final Palaeolithic and Mesolithic (Ksenzov 1999). U. Ksiandzou used the concept of the variability of tools, burinscraper markers, the presence or absence of geometric microliths (trapezes) in the collections as chronologi- cal benchmarks. This allowed for the distinguishing of three chronological stages in the development of the culture (Ksenzov 1999). However, the scheme has not found support among Belarusian researchers (Kopytin 1992, p. 12; Arkhealogiia Belarusi 1997, pp. 39-55; Kalechits 2003, p. 47), because the age of some Grensk sites distinguished by U. Ksiandzou did not correspond with the actual palaeogeographic situation.

U. Ksiandzou's dating of individual monuments of Grensk culture as Late Mesolithic is rather arguable, for he based it only on the fact of the presence of trapezes in the collections. Indeed, tall and medium-height trapezes were found among flint tools at the Rekord and Rečyca-2 sites. But these collections were formed by surface gathering. Besides the Grensk tools, they also include Kudlayevka Mesolithic culture, Neolithic and Bronze Age materials. Therefore, the presence of trapezes, in my opinion, is not a reliable indicator of the late Mesolithic character of Grensk culture, as this group of microliths may refer to the Kudlayevka finds that U. Ksiandzou himself admitted (Ksenzov 1999).

However, taking into account the radiocarbon dates, the occurrence of sites with trapezes in Ienevo culture in the Volga and Oka interfluve relates to the second half of Preboreal and Early Boreal times (Kravtsov, Sorokin 1991, pp. 38-60; Kravtsov 1999). This conclusion was also made by L. Zaliznyak, when he considered the problem of the chronology of Pesochny Rov culture in the Desna basin (Zalizniak 2005, pp. 60-62). However, there is an idea that Ienevo culture in the Volga and Oka interfluve could be much older (Sorokin 2006, pp. 68-85; Sorokin, Oshibkina, Trusov 2009). The accuracy of absolute dates for this culture is doubtful, which, according to A. Sorokin, could be explained by 'the phenomenon of the natural rejuvenation of palynological spectra and radiocarbon samples' (Sorokin 2006, p. 81). Ienevo culture, according to A. Sorokin, might have been Final Palaeolithic, and hence the Ienevo tradition could stand alongside Ahrensburg, Grensk, Pesochny Rov and Ust-Kama cultures.

If Sorokin's conclusions are right, then it is necessary to recognise that both Grensk culture and the IenevoPesochny Rov complexes with trapezes could be older. However, if the trapezes are treated as one of the chronological criteria for a culture, then it should be noted that such forms are known at some Grensk sites. For example, the flint inventory from the Chvojnaja site contained a rough asymmetrical trapeze, stratigraphic observations dating it to the Early Younger Dryas, as mentioned before (Kopytin 1992, pp. 25-27). The Hrensk site collection also contained trapezes, but the lack of expressive stratigraphy of the site, and the 
presence of asynchronous materials, do not let us link these microliths particularly to the Grensk complex.

The author has recently managed to locate several sites in the Sozh basin in eastern Belarus with geometric microliths (Bartalamiejeŭka-2, Zahorjje [Žavyniec], Zaliaddzie, Novyja Hramyki-4, Kalinin [Čurylava], Pieršakryčaŭski-3, Ramanavičy, Jakuboŭka-2). The flint inventory from these sites includes single-platform and double-platform cores and the use of solid crack techniques to produce flakes and blade flakes. Among the tools with secondary processing in the collections of the Sozh basin sites, there are symmetrical and asymmetrical tall trapezes, asymmetrical shouldered points with a notch, and tanged points on blade blanks. This complex can be complemented with a series of large truncated pieces and triangles which are most typical of the sites of the Desna basin.

Paying attention to the whole range of problems of 'the circle of cultures of asymmetrical shouldered points', we cannot ignore the work of Polish researchers. Thus, the Polish archaeologist S.K. Kozłowski proves Grensk culture (or Desna culture in Polish scientific terminology) to be Palaeolithic. 'The Palaeolithic aspect of Desna culture,' says S.K. Kozłowski, 'its chronology, cartographical data and the presence of Desna elements in Swiderian finds, prove that this was a late Palaeolithic culture that developed in the early postglacial period' (Kozłowski 1991, p. 99). S.K. Kozłowski dated the beginning of the formation of Desna culture to the ninth millennium $\mathrm{BC}$, and the time of its existence until the Early Holocene (Kozłowski 1991; Kozlowski 1999, pp. 30-35). It was after the end of the glacial period, according to S.K. Kozłowski, that the transformation of Desna antiquities into a number of 'post-Desna' cultures began.

According to K. Szymczak, the Desna elements in monuments of northeast Poland had existed during the Allerød-Boreal period (Szymczak 1995, p. 70). Similar views are held by the Belarusian researcher W. Obuchowski, who admits the possible interaction between Volkushian and Grensk people 'no later than in midDryas III' (Obukhovskii 2007, p. 159).

Z. Sulgustowska pointed out the vast migrations of the Grensk population westwards in the Boreal period (Sulgostowska 2005, p. 134). In her opinion, the reason for this active mobility of Grensk hunters was the exploration and production of hematite, deposits of it being known around the town of Rydno. However, despite the presence of asymmetrical shouldered points in the flint complexes in the area examined, we cannot accept the fact that the Grensk population of the Upper Dnieper and the Sozh basins, both regions being rich in deposits of cretaceous flint, deliberately travelled so far in order to obtain completely different raw materials. This supposition is confirmed by the absence of hematite products in the flint inventory of the Dnieper and Sozh sites of Grensk culture.

\section{Conclusions}

Thus, the question of the genesis of Grensk culture has brought to life two well-grounded yet diametrically opposed concepts. One of them (U. Budzko, V. Kapytsin, A. Kalechyts, A. Chubur, G. Sinitsyna, etc) develops the idea of the autochthonous origin of the Grensk tradition, trying to link it with the Late Palaeolithic (Magdalenian) period of the centre of the East European Plain (Bud'ko 1966; Bud'ko, Sorokina 1969; Kopytin 1992; Kopytin 1999; Kopytin 2000; Kalechyts 2003; Chubur 2004; Sinitsyna 2008; Sinitsyna 2013). The second group of researchers (L. Zaliznyak, U. Ksiandzou, A. Sorokin, etc) show that the genetic basis of Grensk culture formed on the Bromme-Lyngby traditions, which came from the west to the Upper Dnieper region (Ksenzov 1997; Ksenzov 1999; Ksenzov 2006; Zalizniak 2005; Sorokin 2008; Sorokin, Oshibkina, Trusov 2009; Sorokin 2016). In any case, the lack of well- stratified monuments with reliable and representative flint complexes makes this question arguable, and still requires relevant research.

It is obvious that 'the Grensk issue' should not be limited to eastern Belarus only, and should be incorporated into mainstream problems of the Final Palaeolithic and Mesolithic ages in the forest belt of Eastern Europe. In this case, the material of Grensk, Ienevo and Pesochny Rov cultures becomes a specific instrument in the study of the cultures of asymmetrical shouldered points in different regions of eastern and northern Europe. In this regard, the Russian researcher E. Leonova was correct in saying that complexes with asymmetrical points formed a 'common information space of which the boundaries are likely to have changed in the course of time' (Leonova 2007, pp. 147-148).

The other question concerns spatial and temporal differences in monuments of Grensk, Pesochny Rov and Ienevo cultures. Is it correct to believe that the history of Grensk culture in the Upper Dnieper region had finished by the beginning of the Holocene, giving way to new cultural impulses of Pesochny Rov and Ienevo type? Among the monuments of Pesochny Rov and Ienevo cultures, Grensk antiquities are recognised by some researchers as the earliest, and are included in a separate local (Upper Dnieper) group, which is not characterised by geometric microliths (Kopytin 1992; Zalizniak 2005, pp. 52-62; Zalizniak 2009, pp. 58-94).

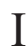

STONE AGE IN NORTHERN EUROPE: CHANGES IN LANDSCAPE, TECHNOLOGIES AND BELIEFS 
The data on Pesochny Rov culture in the Sozh basin (Kolosov 2015) makes it possible to discuss not the presence of a new cultural phenomenon which characterises the Mesolithic Age of a certain region (in this case the Desna basin), but a likely transformation of the culture of Grensk (Krasnosillya, according to L. Zaliznyak) hunters in the post-glacial era. Therefore, the population of the Upper Dnieper region, as well as the Desna basin and the Volga-Oka interfluves, could have been involved in this process.

The cultural identity of the Upper Dnieper region, as well as the Volga-Oka and the Desna basins, all being a part of the 'common information space', is an indicator of the technical and economic changes influenced by environmental factors at the turn of the Pleistocene and Holocene (Balakin, Nuzhnyi 1990). The exploration of monuments provided with natural science dates, in comparison with material from neighbouring areas, will make it possible to trace the genesis and evolution of the flint processing traditions of the Final Palaeolithic population of Eastern Europe, and to determine their role in the formation of the Mesolithic cultures of the area examined, which requires a comprehensive study of the sources.

\section{References}

ARKHEALOGIIA BELARUSI, 1997. Kamenny $i$ bronzavy viaki. Minsk.

AGEEVA, K.E., 2007. Klassifikatsiia i sravnitel'naia kharakteristika nakonechnikov strel i geometricheskikh mikrolitov ienevskoi mezoliticheskoi kul'tury. The Russian archaeology, 4, 121-134.

BALAKIN, S.A., NUZHNYI, D.IU., 1990. Khoziaistvenno-ekonomicheskoe razvitie $\mathrm{v}$ golotsene i problema arkheologicheskikh kriteriev mezolita. Kamennyi vek na territorii Ukrainy: Nekotorye aspekty khoziaistva $i$ etnokul'turnykh sviazei. Kiev, 90-101.

BUD'KO, V.D., 1959. Dnevnik o rabote v Berdyzhe v 1959 g.. The Fund of Archaeological Scientific Documentation of the Central Scientific Archive of the National Academy of Sciences of Belarus, 395, Minsk.

BUD'KO, V.D., 1961. Otchet ob issledovanii pamiatnikov svidersko-grenskoi kultury v 1961 g. The Fund of Archaeological Scientific Documentation of the Central Scientific Archive of the National Academy of Sciences of Belarus, 206, 206a (albom), Minsk.

BUD'KO, V.D., 1962. Otchet o o rabotakh v Grenske v 1960-1961 g. The Fund of Archaeological Scientific Documentation of the Central Scientific Archive of the National Academy of Sciences of Belarus, 346, Minsk.

BUD'KO, V.D., 1966. Pamiatniki svidersko-grenskoi kultury na territorii Belorussii. $U$ istokov drevnikh kultur. Materialy $i$ issledovaniya po arkheologii SSSR, 126. Moskva-Leningrad, 35-46.

BUD'KO, V.D., SOROKINA, R.A., 1969. Pozdnii paleolit Severo-Zapada Russkoi ravniny. Priroda i razvitie pervobytnogo obshchestva. Moskva, 127-136.
BUTRIMAS, A., OSTRAUSKAS, T., 1999. Tanged points cultures in Lithuania. Tanged pointes cultures in Europe. Lublin, 267-271.

CHUBUR, A.A., 2004. Ot Khotyleva do Grenska: vzgliad na drevneishuiu istoriiu tsentra Russkoi ravniny. Desninskie drevnosti- III. Bryansk, 43-50.

KALECHITS, E.G., 1987. Pamiatniki kamennogo i bronzovogo vekov Vostochnoi Belorussii. Minsk.

KALECHITS, E.G., 2003. Chelovek i sreda obitaniia. Vostochnaia Belarus'. Kamennyi vek. Minsk.

KALECHYTS, A.G., KOLASAU, A.U., ABUCHOUSKI, V.S., 2010. Palealitychnyia pomniki Belarusi: (kulturnakhranalagichnaia identyfikansyia krynins). Minsk.

KOLOSOV, A.V., 2005. Mezoliticheskaia stoianka Poklady-2 v Krichevskom Posozh'e. Historical-archaeological collection, 20, 16-20.

KOLOSOV, A.V., 2010. Final'nyi paleolit i mezolit Posozh'ia. Materials on the archaeology of Belarus, 18, 77-89.

KOLOSOV, A.V., 2013. O zaselenii basseina r. Sozh v pozdnelednikovoe vremia. Problemy zaseleniia severo-zapada Vostochnoi Evropy v verkhnem i final'nom paleolite (kul'turno-istoricheskikhie protsesy). St. Petersburg, 181220.

KOLOSOV, A.V., 2015. Final'nyi paleolit i mezolit Posozh'ia. Mogilev.

KOL'TSOV, L.V., 1972. Mezoliticheskii sloi stoianki Altynovo. Kratkie soobshchenia Instituta arheologii, 131, 87-90.

KOPYTIN, V.F., 1992. Pamiatniki final'nogo paleolita $i$ mezolita Verkhnego Podneprov'ia. Mogilev.

KOPYTIN, V.F., 1994. Nekotorye itogi izucheniia Grenskoi stoianki. Historical-archaeological collection, 4, 34-59.

KOPYTIN, V.F., 1999. Final'nyi paleolit i mezolit Verkhnego Podneprov'ia. Tanged pointes cultures in Europe. Lublin, 256-266.

KOPYTIN, V.F., 2000. U istokov grenskoi kultury. Borovka. Mogilev.

KOPYTIN, V.F., 2005. Final'nyi paleolit Verkhnego Podneprov'ia kak istoricheskaia epokha. Historical-archaeological collection, 20, 5-15.

KOZŁOWSKI, S.K., 1991. Le Desnenien. Anthropologie, $X X I X / 1-2,95-100$.

KOZŁOWSKI, S.K., 1999. The tanged Points Complex. Tanged points Cultures in Europe. Lublin, 28-35.

KRAVTSOV, A.E., 1999. Concerning the dating of the Yenevo culture. Tanged pointes cultures in Europe. Lublin, 272-279.

KRAVTSOV, A.E., SOROKIN, A.N., 1991. Aktual'nye voprosy Volgo-Okskogo mezolita. Moscow.

KRAVTSOV, A.E., ZHILIN, M.G., 1995. Opyt funktsional'no-planigraficheskogo analiza mezoliticheskoi stoianki Belivo-4G-severnaia. The Russian archaeology, 2, 135-147.

KSENZOV, V.P., 1988. Paleolit $i$ mezolit Belorusskogo Podneprov'ia. Minsk.

KSENZOV, V.P., 1997. Final'nyi paleolit i mezolit Podneprov'ia Belarusi. The Russian archaeology, 1, 5-20.

KSENZOV, V.P., 1999. Novye pamiatniki grenskoi kultury $\mathrm{v}$ Belorusskom Podneprov'ie. Tanged pointes cultures in Europe. Lublin, 229-239.

KSENZOV, V.P., 2006. Mezolit Severnoi i Tsentral'noi Belarusi. Materials on the archaeology of Belarus, 13. Minsk.

LEONOVA, E.V., 2007. K probleme arkheologicheskogo soderzhaniia ienevskoi kul'tury Volgo-Okskogo basseina. 
Problemy arkheologii kamennogo veka (k iubileiu M.D. Gvozdover). Moscow, 119-154.

LISITSYN, S.N., 2017. Ekologicheskii podkhod k periodizatsii final'nogo paleolita i rannego mezolita v Verkhnevolzhskom regione. Stratum plus, 1, 59-110.

OBUCHOVSKII, V.S., 2007. "Grenskii sled" v final'nom paleolite mezhdurech'ia Nemana, Pripiati i Visly. Romanovskie chtenia-3. Mogilev, 157-161.

OBUCHOWSKI, W., 2009. Materiaty paleolityczne i mezolityczne z zachodniej Białorusi. Swiatowit, Vol. XVI. Warszawa.

POPLEVKO, G.N., 2007. Metodika kompleksnogo issledovaniia kamennych industrii. Trudy Instituta istorii material'noi kul'tury, 23. St Petersburg.

RIMANTENE, R.K., 1971. Paleolit i mezolit Litvy. Vilnius.

SINITSYNA, G.V., 2008. Zaselenie Valdaiskoi vozvyshennosti na rubezhe pleistocena - golocena. Put' na Cever: okruzhaiushchaia sreda i samye rannie obitateli Arktiki i Subarktiki. Moscow, 161-172.

SINITSYNA, G.V., 2013. O migratsiiach i avtochtonnom razvitii kultur final'nogo paleolita na severo-zapade Russkoi ravniny. Problemy zaseleniia severo-zapada Vostochnoi Evropy $v$ verkhnem i final'nom paleolite (kul turno-istoricheskikhie protsesy). St. Petersburg, 152-181.

SOROKIN, A.N., 2002. Mezolit Zhizdrinskogo Poles'ia. Problema istochnikovedeniia mezolita Vostochnoi Evropy. Moskva.

SOROKIN, A.N., 2004. Mezolit Volgo-Okskogo basseina. Problemy arkheologii kamennogo veka Russkoi ravniny. Moscow, 59-89.

SOROKIN, A.N., 2006. Problemy mezolitovedeniia. Moskva.

SOROKIN, A.N., 2008. Mezolitovedeniie Pooch'ia. Moskva.

SOROKIN, A.N., OSHIBKINA, S.V., TRUSOV, A.V., 2009. Na perelome epokh. Moskva.

SOROKIN, A.N., 2016. Stoianka Shagara 4 i mezolit Meshcherskoi nizmennosti. Materialy okhrannykh arkheologicheskikh issledovanii, 18. Moskva.

SULGOSTOWSKA, Z., 2005. Konakty społeczności późnopaleolitycznych $i$ mezolitycznych między Odra, Dzwina i górnym Dniestrem. Warszawa.

SZYMCZAK, K., 1995. Epoka kamienia Polski Pótnocno-Wschodniej na tle środkowoeuropejskim. Warszawa.

TAUTE, W., 1968. Die Stielspitzen-Gruppen im nördlichen Mitteleuropa. Ein Beitrag zur Kenntnis der späten Altsteinzeit. Köln.

ZALIZNIAK, L.L., 1999. Final'nyi paleolit pivnichnogo zachodu Shidnoi Evropy. Kiev.

ZALIZNIAK, L.L., 2005. Final'nyi paleolit $i$ mezolit kontynental'noi Ukrainy. Kul'turnyi podil ta periodyzatsiia. Kam 'iana doba Ukrainy, 8. Kiev.

ZALIZNIAK, L.L., 2009. Mezolit zachodu Shidnoi Evropy. Kam'iana doba Ukrainy, 12. Kiev.

Received: 12 February 2018; Revised: 3 March; Accepted: 12 April 2018

Aliaksandr U. Kolasau

Chair of Archaeology and Special Historical Disciplines

Faculty of History and Philology

Mogilev State A. Kuleshov University

Kasmanaŭtaŭ St 1

212022 Mahilioŭ

Belarus

Email: kolosov_arc@mail.ru
GRENSKO KULTŪRA

RYTU BALTARUSIJOJE:

DABARTINÉ TYRIMŲ

SITUACIJA

\section{Aliaksandr U. Kolasau}

\section{Santrauka}

Autorius nagrinèja modernios istoriografijos problemas, susijusias su finalinio paleolito ir mezolito Grensko kultūra Rytų Baltarusijoje. Ši kultūra vienija paminklu grupę, kuriai būdinga tradicija naudoti specialius asimetriškus antgalius su šonine briauna, žinomus kaip Grensko tipo antgaliai.

Šių dirbiniu geografija neapsiriboja tik Aukštutinio Dniepro regionu - tokių dirbinių randama ir ịvairiose Rytų bei Šiaurès Europos teritorijose, tačiau jie priklauso kitoms kultūroms: Jenevo kultūrai Volgos ir Okos santakoje, Pesočnyj Rovo (angl. Pesochny Rov) kultūrai Dniepro baseine, Fosnos ir Komsos kultūroms Skandinavijoje. Ukrainos archeologas L. Zalizniakas identifikavo vietas su šiais asimetriškais antgaliais atskiroje Krasnoseljès kultūroje. Lenkų istoriografijoje ji yra žinoma kaip Desnos kultūra. Neapibūdinus archeologinès medžiagos, neįmanoma suprasti nesutarimų dèl ginčytino Grensko kultūros susiformavimo ir chronologijos bei esamų ryšiu su kaimyninèmis teritorijomis. Visi tie klausimai yra šio straipsnio objektas.

Šiuo metu Baltarusijoje yra daugiau nei 40 vietų su Grensko kultūrai priskiriama medžiaga (1 pav.). Daugelis Grensko kultūros paminklu yra lokalizuota viršutiniame Dniepro regione: Dniepro baseino - Varovka, Dalniaje Liada, Karomka, Ludčycy, Maloje Zarečča (Šklovas Zarečny), Magiliovskaja, Orša-1, Rekord, Chvojnaja; Sožès baseino - Grenskas, Žuraviel, Paklady-2; Besedès baseino - Vitūnas-5A, Piečaniežo; Berezinos baseino - Huta-1; Drutès baseino - Viryčiavas, Višanka, Čygirinka ${ }^{1}$.

Grensko kultūros medžiotojai teikè pirmenybę vietoms, esančioms šalia kreidinio titnago telkinių, ypač tais atvejais, jei ši žaliava būdavo arti žemès paviršiaus arba pačiame paviršiuje, o taip yra, pvz., Dniepro baseine. Žaliavos prieinamumas dare įtaką titnago dirbinių gamybos technikai.

\footnotetext{
Baroŭka (the sites mentioned here and below have been studied only by excavations), Daĺniaje Liada, Karomka, Ludčycy, Maloje Zarečča (Škloŭ Zarečny), Mahilioŭskaja, Orša-1, Rekord, Chvojnaja, in the Sozh basin - Hrensk, Žuravieĺ, Paklady-2, in the Biesiadź basin - Vituń-5A, Pechenezh, in the Biarezina basin - Huta-1, in the Druć basin - Viryčaŭ, Višańka, Čyhirynka.
}

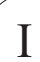

STONE AGE IN NORTHERN EUROPE: CHANGES IN LANDSCAPE, TECHNOLOGIES AND BELIEFS 
Titnago apdirbimo vietose tarp titnago inventoriaus yra daug (iki 80 proc.) gamybos atliekų. Grensko kultūrai būdinga tiesioginio smūgio technika, tai pastebima iš Hrensk'o, Žuravieë, Paklady-2 gyvenviečių titnaginio inventoriaus ir skaldytiniu morfologijos. Tarp jų dominuoja vienagaliai skaldytiniai (40-60 proc.), taip pat yra nedidelis skaičius dvigalių skaldytiniu $(2.33,34$ pav.). Pagrindiniai ịankiai buvo gaminami iš nuoskalų, rečiau - iš taisyklingų skelčių.

Grensko kultūros titnago rinkinyje dominuoja galiniai, taip pat dvigubi, apskritimo formos gremžtukai (2.21-23 pav.). Antrojoje grupeje aptinkama gausybé rěžtukų. Labiausiai paplitę buvo kampiniai, dvigubų ašmenų ir kombinuotieji rèžtukai (2.28-30 pav.). Grensko ịrankių komplektą papildo kampiniai ir dviašmeniai grąžtai; simetriški ir asimetriški antgaliai; skeltės su skersiniu retušu; pjaustymo įrankiai su pleišto formos ašmenimis ir pergniaužtiniai kirviai (2 pav.).

Grensko kultūroje išskiriamos dvi pagrindinès antgalių formos (2.1-16 pav.). Viena iš jų yra vadinamieji antgaliai su ịvairiomis ịkotemis ir smaigaliais (2.1-8 pav.). Antrają grupę sudaro asimetriški antgaliai su peteliais, šone turinčiais igaubą (2.9-16 pav.).

Grensko kultūros genezès klausimas nagrinejjamas dvejopai. Vieni archeologai (U. Budzko, V. Kapytsin, A. Kalechyts, A. Chubur, G. Sinitsyna ir kt.) plettoja autochtoninès kilmès Grensko kultūros ideją, bandydami sieti ją su vèlyvuoju paleolitu (Madleno kultūra) Rytų Europos lygumose. Antroji tyrejų grupè (L. Zaliznyak, V. Ksenzov, A. Sorokin ir kt.) įrodinèja, kad technologinị Grensko kultūros pagrindą sudaro Bromės-Liungbiu technologiniai kompleksai, kurie aukštutinį Dniepro regioną pasiekè iš Vakarų Europos.

Dẻl stratifikuotų gyvenviečių ir gamtos mokslų tyrimų duomenų trūkumo kyla nemaža sunkumų, siekiant detaliau pažinti Grensko kultūrą.

Grensko kultūros kilties tyrimas turètų būti susietas su bendru Rytų Europos miško juostos finalinio paleolito ir mezolito laikotarpiais nagrinèjimu. Kultūrinis identitetas aukštutinio Dniepro, Volgos ir Okos bei Desnos baseinuose, kuriuose paplitę asimetriniai antgaliai su peteliais, yra technologinių ir ekonominių pokyčių rodiklis, kuriam įtakos turejo besikeičianti pleistoceno ir holoceno gamtinè aplinka ir kaimyninès kultūros. 